\title{
Tense and Aspect in Performative Utterances in Bulgarian
}

\author{
Svetlana Slavkova \\ Department of interpretation and Translation \\ Bologna University \\ Forlì, Italy
}

\begin{abstract}
Bulgarian differs from the other Slavic languages in that performatives are used in a somewhat wider range of tense-aspectual forms than the (always imperfective) present, which is the classic form for performative utterances in general. In fact, performatives occur in the analytical future, both perfective and imperfective. This paper aims to identify the parameters determining tense-aspectual choices in performative verbs in Bulgarian and to highlight the pragmatic meaning of such choices. In particular, the paper puts forward the hypothesis that tense and aspect in Bulgarian performative utterances can perform specific functions related especially to interpersonal distance and linguistic politeness.
\end{abstract}

Keywords-performative verbs; aspect; tense; politeness; Bulgarian

\section{INTRODUCTION: ASPECT IN BULGARIAN}

Before tackling the issue of the aspect of performative verbs in Bulgarian we shall briefly consider the Bulgarian aspectual system within the typical framework of the Slavic languages.

It is well-known that in Bulgarian, as in the other Slavic languages, almost all verbs form aspectual pairs consisting of two verbs having the same lexical meaning, one verb being PF and the other IPF 1 Each aspect, perfective and imperfective, can convey a set of aspectual meanings:

IPF: states (znaja), processes (rabotja, četa, rešavam), iterated events (pročitam, napisvam, namiram);

PF: single events (pročeta, namerja, napiša, reša).

The imperfective and the perfective in all Slavic languages are formally distinguished by the theme of the verbal lexeme, i.e. the dictionary form of each individual verb. 2 Thus in Bulgarian the verbs piša, četa, namiram,

Cf. one of the definitions of aspectual pair: "Aspectual pair is constituted by two verbs, one in the Pfv, another in the Ipfv, satisfying the following condition, see (Maslov 1948): the verb in the Ipfv must be able to express - perhaps among its other meanings - the meaning of iteration of the situation denoted by the Pfv. (Another criterion - supposedly extensionally equivalent to the first one: the Ipfv must be substitutable for the Pfv in the context of praesens historicum.)" [1].

And consequently, in all forms, both finite and non-finite. In this way, for Bulgarian we will have the imperfectives piša, pisax, pišex, pisal săm, pišel săm ecc. vs. the perfectives napiša, napisax, napišex, napisal săm, napišel săm etc. želaja are imperfective while napiša, pročeta, namerja poželaja are perfective. 3

Moreover, in Bulgarian, unlike in most Slavic languages, the complex Old Slavonic system of verb tenses is maintained and enriched with forms and meanings. 4 The Bulgarian linguist L. Andrejčin distinguishes three absolute tenses (aorist, praesens, futurum) and six relative tenses: perfectum, plusquamperfectum, imperfectum, futurum preteriti, futurum exactum, futurum exactum preteriti [3]. More recent grammars list the same absolute and relative tenses (perfectum, aorist, praesens, futurum, plusquamperfectum, imperfectum, futurum preteriti, futurum exactum, futurum exactum preteriti) [4].

Thus in Bulgarian we find two fundamental oppositions which play an active part in forming the aspectual meaning of a phrase: the aorist : imperfect opposition (which appears only when referring to the past) and the perfective : imperfective opposition (based on other, more complex semantic features which appear in all verbal forms, both finite and infinite). In other words, in Bulgarian there is the integrated action of various aspectuality indicators, which are obligatory and operate on the basis of extremely precise rules. Overlap (which at times involves reduplicating or eliminating certain aspectual features), and combinations of lexical-grammatical means and the aspectual meaning of the grammatical tenses together create a framework which is

The same applies for all the Slavic languages (cf. the aspectual pairs in Russian pisat' - napisat'; čitat' - pročitat'; nachodit' - najti and in Czech psát-napsat; číst - přečíst; ptát se - zeptát se; najit - nacházet; nalézt - nalézat) unlike Italian, for example, where the aspectual meaning is expressed by the ending of the conjugated verb: andai - andavo and by the progressive form: stavo andando.

The tense system in ecclesiastical texts from the Old Bulgarian period is characterised by great variety. Specifically it includes the following verbal tenses: present, future, aorist, imperfect, perfect and pluperfect. In eastern and western Slavic languages (and thus in the majority of Slavic languages), the system of past tenses has been simplified, and is concentrated in a single past tense which corresponds formally to the perfect (sometimes with loss of the auxiliary). This has not happened in Bulgarian. It is believed that the perfect in Bulgarian had already been reanalysed semantically in the 13th-14th century, subsequently becoming the basis for a complex system of renarrative forms (i.e. of the category of evidentiality) [2]. 
more complex than the Slavic model in general.5 "Table I" shows the tense-aspectual forms in Bulgarian.

TABLE I.

\begin{tabular}{|c|c|c|c|}
\hline & $\begin{array}{c}\text { Bulgarian } \\
\text { Tenses }\end{array}$ & $\begin{array}{c}\text { Imperfective } \\
\text { Aspect }\end{array}$ & $\begin{array}{c}\text { Perfective } \\
\text { Aspect }\end{array}$ \\
\hline \multirow{4}{*}{$\begin{array}{c}\text { Absolute } \\
\text { tenses }\end{array}$} & perfectum & pisal săm & hapisal săm \\
\hline & aorist & pisax & hapisax \\
\hline & praesens & piša & (da) napiša \\
\hline & futurum $^{6}$ & šte piša & šte napiša \\
\hline \multirow{5}{*}{$\begin{array}{c}\text { Relative } \\
\text { tenses }\end{array}$} & $\begin{array}{l}\text { plusquamperfectu } \\
\text { m }\end{array}$ & bjax pisal & bjax napisal \\
\hline & imperfectum & pišex & napišex \\
\hline & futurum preteriti & štjax da piša & štjax da napiša \\
\hline & futurum exactum & šte săm pisal & šte săm napisal \\
\hline & $\begin{array}{l}\text { futurum exactum } \\
\text { preteriti }\end{array}$ & štjax da săm pisal & $\begin{array}{l}\text { stjax da săm } \\
\text { hapisal }\end{array}$ \\
\hline
\end{tabular}

A further peculiarity of Bulgarian concerns the morphological-derivational relations between members of an aspectual pair which are seen in the process of regular secondary imperfectivisation. Through this process, from perfective verbs (obtained from simple imperfective verbs by prefixing: želajaIPF $\rightarrow$ poželajaPF [wish]), new imperfective verbs are formed using a number of specialised suffixes (poželajaPF $\rightarrow$ poželavamIPF [wish]). In this way it is as if two aspectual pairs were formed: a primary pair (IPF base verb with no prefix: derived PF verb with prefix) and a secondary pair (PF derived verb with prefix: derived IPF verb with prefix and suffix).7

In addition to the specific morphological features of the aspectual forms of the verb, it is also necessary to consider the semantic class to which each individual verb belongs. In this connection it should be remembered that modern studies of verbal aspect in Slavic languages are based substantially on two fundamental contributions which to some extent have determined subsequent research. They are Maslov, which deals with the aspect in Russian (but is also applicable to the other Slavic languages, and in particular to Bulgarian) and Vendler, which although focusing on English can be applied to other languages [5] [6]. In both studies, a clear distinction is drawn for the first time between the various semantic classes of verbs in relation to their tense-aspectual features. Vendler identifies four large semantic classes of verb (states,

Cf. for example Russian, where the only existing morphological opposition is between the past tense and non-past tenses

Unlike in other Slavic languages, in Bulgarian the perfective present form is never used with future meaning (Cf. Russian skažu, Czech reknu, Slovene povem), the only form existing being the periphrastic future tense expressed by the invariant particle šte. This is the main difference between Bulgarian and the majority of Slavic languages (excepting Macedonian and Slovene).

Unlike in other Slavic languages, in Bulgarian the perfective present form is never used with future meaning (Cf. Russian skažu, Czech $\check{r}$ eknu, Slovene povem), the only form existing being the periphrastic future tense expressed by the invariant particle šte. This is the main difference between Bulgarian and the majority of Slavic languages (excepting Macedonian and Slovene). activities, achievements, accomplishments) and shows how the fact that a verb belongs to one class rather than another has a series of implications at the aspectual level, for example limiting the verb's possibility of taking certain tense forms which carry specific aspectual meanings. Based on the semantic meaning of the verbal theme, Maslov distinguishes imperfectiva tantum verbs (which correspond to Vendler's states and activities) and verbs which form an aspectual pair.

The latter type in turn are divided into classes, among which the main ones are telic verbs (predel'nye) and punctual verbs (momental'nye). The former correspond to Vendler's accomplishments and form telic (or terminative) aspectual pairs (risuvamIPF - narisuvamPF [draw]). This is due to their inherently telic 8 meaning, which enables the attainment of the result of a potentially bounded dynamic process (or also a natural conclusion, as in the case of topja seIPF $\rightarrow$ stopja sePF [melt]) to be expressed. 9The second group of verbs (achievements in Vendler's classification) form aspectual pairs which, because of the type of relation between the two elements, can be defined as quantitative. 10The perfectives of these verb pairs (which are bounded) name a single punctual event, while the imperfectives (which in any case maintain their boundedness) express an indefinite quantity of punctual events, i.e. they assume iterative meaning. 11Often these imperfectives are derived from the perfectives using the suffixes -a- (with vowel alternation in the stem: namerjaPF $\rightarrow$ namir-a-mIPF [find]; pročetaPF $\rightarrow$ pročit-a-mIPF [read]), -va-(postrojaPF $\rightarrow$ postroja-va-mIPF [build]; napišaPF $\rightarrow$ napis-va-mIPF [write]; kažaPF $\rightarrow$ kazva-mIPF [say]), -uva- (kupjaPF $\rightarrow$ kup-uva-mIPF [buy]).12

Used in the present (the tense which is the main focus of this paper), the imperfective verbs in Vendler's class of accomplishments usually express process during its performance and can therefore be used as a reply to the question Kakvo praviš $\mathrm{v}$ momenta? [What are you doing now?]. On the other hand, achievements in the present can refer to individual actions in the praesens historicum 13 or to

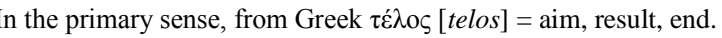
This term corresponds to "vnutrennij predel" in the aspectological terminology of the Russian tradition. Cf. [7] on telicity (44-8).

9 Resultativity is closely linked to the transitive nature of many verbs in this group since the resultative component of the lexical meaning is activated (or supported) precisely because of the presence of a direct object.

In [8], [9], [10] this type of pair is called trivial'naja para (trivial pair) in the sense that between the members of the pair only a quantitative relation exists, unlike all the other types of pairs (including terminative pairs), in which a further type of semantic relation (for example process result) is added to the quantitative relation (which in a certain sense is taken for granted).

11 Cf. also [7]: 43.

12 Note that according to A. Dostál the historical primary meaning of the suffixes -a-, -va- is iterative ([11]: 568-569).

13 This fact is demonstrated indirectly by Maslov which claims that imperfective verbs used in the form of the praesens historicum may also correspond to perfective verbs in the past, which convey punctual actions (achievements) ([5]: 315). Cf. also Vendler on the use of achievements in the praesens historicum: "As a matter of fact the point can be made stronger still: in cases of pure achievement terms the present tense is almost exclusively used as historic present or as indicating immediate future" ([6]:103). 
habitual events; unlike imperfective telic verbs, they cannot be used to report the actual process. 14

We will now analyse some performative verbs from the point of view of aspect and semantic class. To do so we will examine some examples of non-performative use of performative verbs. What we are interested in is contexts where the imperfective-perfective opposition is evident. For Bulgarian these are utterances in the future (we will exclude the past to avoid using the imperfect and aorist):

- (1a) Tuk avtorăt šte preporăčvaIPF-FUT interesni knigi i filmi. [Here the author will suggest some interesting books and films]

- (1b) EK šte preporăčaPF-FUT otmjanata na vizite za Albanija i Bosna. [The EC will suggest the cancellation of the visas for Albania and Bosnia]

- (2a) Latvija šte kaniIPF-FUT stroiteli ot čužbina, mestnite izbjagali. [Latvia will invite builders from abroad, since local builders have left].

- (2b) Părvanov šte pokaniPF- FUT avtorite na pismoto, koito iskat referendum. [P. will invite the authors of the letter who are requesting the referendum]

In example (1a) the Speaker wishes to point out where recommended readings will be published regularly (the sentence is equivalent to: This is where interesting films and books will be recommended regularly). Similarly, in example (2a), the action of "inviting" refers to the entire territory of Latvia and will involve numerous foreign builders Both šte preporăčvaIPF- FUT and šte kaniIPF-FUT therefore express not processes, but iterated events. Moreover, in both examples, the imperfective of the verb is supported by an indefinite plural (knigi i filmi [books and films]; stroiteli [builders]).

Examples (1b) and (2b) instead refer to events which are understood as being single and definite. This interpretation is also supported by the definiteness of the arguments of the predicate, rendered with the post-positioned definite article (otmjanata na vizite [the cancellation of the visas]; avtorite na pismoto [the authors of the letter]).

Even when used in the present, it is difficult to conceive of the imperfective of the verbs in question (in addition to preporăčvam [suggest] and kanja [invite], we can include molja [ask], săvetvam [advise], otkazvam [refuse], razrešavam [allow], iziskvam [require], zabranjavam [forbid] ecc.) being used to express process. As already stated, the present form of these verbs is used in utterances in the praesens historicum (examples 3 and 4):

- (3) Sled navlizaneto na vojskite, toj go predupreždava i mu zabranjava IPF-PRES da izliza ot vkăšti. [After the advance of the army, he informs him and forbids him to leave the house]

- (4) G. otkazva IPF-PRES i go predupreždava, če M. E iskal prosto da mu pomogne $\mathrm{i}$ ako toj ne ocenjava

14 In the Russian terminology aktual'no-dlitelnoe or konkretnoprocessnoe značenie. tova, toj njama da mu pomogne po njakakăv način. [G. refuses and informs him that $\mathrm{M}$. only wanted to help him, and should he not appreciate it, will not help him in any way]

So, as can be seen from examples (3) and (4), the use of imperfective performative verbs in the historical present is intended to express single events and not process. Thus a question regarding an action in progress appears to be impossible (example 5):

- (5)Kakvo praviš v momenta? - ?V momenta zabranjavam IPF-PRES / razrešavamIPF-PRES na sina si da izliza. [What are you doing now? -?I'm allowing/forbidding my son to go out]

This too provides confirmation that the verbs in question are members of "trivial" (quantitative) aspectual pairs, that is to say, from the point of view of aspectual semantics, they belong to Vendler's achievements class. Summing up, in this type of aspectual pair, both the perfective and the imperfective indicate events: the perfective verb indicates a single event $(\mathrm{E}=1)$ while the imperfective indicates an indefinite quantity of events $(\mathrm{E} \geq 1)$.

\section{PERFORMATIVE VERBS FROM THE VIEWPOINT OF TENSE AND ASPECT}

Performative sentences are studied in detail in speech act theory from the point of view of the type of illocution by means of which the Speaker manifests his communicative intention [12] [13]. The pragmatic dimension was later enriched by research into communicative cooperation between participants in a conversation, social and linguistic conventions (cf. Leech's politeness principle in, and linguistic politeness and related strategies [14] [15] [16].

From a semantic and grammatical viewpoint, and more precisely regarding the issue of tense in performative utterances, it is usually remarked that they take the form of first person singular, present tense indicative active of the performative verb [12] [13], [17].

However, in the field of Slavic languages the problem also arises of the aspectual characteristics (and for Bulgarian also the tense characteristics) of the verbs which determine the performative status of the utterance. This particular focus on performative verbs from the point of view of their aspectual semantics is due to the fact that in many Slavic languages both the imperfective and the perfective verb can be used in the same illocutionary act. It thus becomes necessary to identify criteria for selecting the correct aspect, and the subtle mechanisms of their functioning according to communicative intention.

The performatives in Slavic languages are dealt with in [18] [19] [20] [21]. All three underline in particular that there are Slavic languages which in the present only allow the use of perfective performatives (Czech, Slovak), while in others (Russian and Slovene, but also Polish) alongside the 
imperfective present, the perfective present 15 is used, albeit more rarely.

In studies on Russian, a part of the research on illocutionary acts shifts the focus to the issue of the tenseaspectual meaning of verbs used in performative utterances [22] [23] [24] [25]. Starting from the well-known consideration that the use of imperfective verbs in the present in performative utterances produces the effect of "completing" the action, often also signalling a new "state of things" 16 (naznačaju na dolžnost' [I appoint sb. to sth.], obvinjaju [I accuse], osuždaju [I sentence]) it is underlined that in the performative act the imperfective verb acquires a "resultative" meaning and thus "draws closer" semantically to perfectives and momentaneous verbs in general. In this way, for Apresjan, with performative use of the verbs in question a phenomenon of "levelling" (nivelirovka) of the aspectual differences takes place [22]. A consequence of this "levelling" is reflected in the possibility of replacing the imperfective verb in the present (prošu [ask/beg], sovetuju [advise/recommend]) with the perfective in the present (poprošu [ask/beg], posovetuju [advise/recommend]). This fact can only be explained if we consider that the abovementioned imperfective forms, as we saw in section 1, belong to the semantic class of achievements and both verbs, the perfective and the imperfective, have bounded meaning. It would however be wrong to think that we can always use $\mathrm{PF}$ or IPF indiscriminately. The distinctive function of verb aspect in differentiating performative utterances in Russian is analysed for example in [24], where the use of perfective poprošu alongside imperfective prošu 17 is explained by the fact that in this case the choice of aspect determines distinct speech acts, "request-supplication" (pros'ba) and "requestorder" (trebovanie) respectively [24]

The meaning of the imperfective present in performative utterances in Russian is considered by Apresjan to be at one and the same time punctual (točečnoe značenie) and referring to process, since despite the resultative meaning of the perfective verb, actually uttering the act is characterised by a duration in time (however short) [22]. Regarding the situations described by performative sentences, or more precisely by performative verbs in the present tense, Comrie suggests that "they can be conceptualized as momentaneous, especially in so far as the time occupied by the report is exactly the same as the time occupied by the act" [26]. In another study regarding the use of prescriptive performatives of command in the Bible, the meaning of the present of the performative verb has been described as a "closed" present since the illocutionary act is concentrated on the verbal lexeme. In this sense the present of performative verbs can

\footnotetext{
15 For the Slavic languages we will use the terms imperfective
} present and perfective present (the perfective present in most Slavic languages corresponds to the synthetic "one-word" future tense). For Bulgarian we will use the terms present tense and periphrastic future tense (which may be either imperfective and perfective).

16 Note that the expression of a new state of things, due to a qualitative change in the situation, is the main aspectual function of perfective verbs in general.

17 Note that the perfective present form (poprošu) in Russian functions as a simple future and therefore the choice of the perfective automatically shifts a performative utterance into the future. be described as a perfectivised present, since in actual fact the utterance produces an evident "momentaneous effect" [27].

Koshmieder, when analysing the phenomenon of "coincidence" 18 in Polish, had already stressed that the present form of performatives cannot be perceived as having processual meaning and that the form of the future (especially of verba dicendi) has no authentic future meaning but rather acquires a modal shade of meaning, at times being perceived as a politer form ([28]: 163-5).

Among the fundamental contributions to this discussion in the field of Bulgarian, the pioneering work of R. Nicolova dedicated to speech acts in Bulgarian must be mentioned [29]. The author, taking into consideration the work of Austin and Searle, proposes a classification of speech acts based on a rather extensive sample of the Bulgarian language. Other authors instead deal with the issue of speech acts from the viewpoint of the choice of pragmatic instruments in communication, from the lexicographical point of view and from a sociolinguistic perspective respectively [30] [31] [32].

With regard to the role of grammatical categories, Nicolova dwells upon the functions of the complex tenseaspectual system in Bulgarian and, though not dedicating specific attention to performative verbs, stresses the following in connection with aspect: "Pragmatični moment pri upotrebata na vida se pojavjavat tam, kădeto govoreštijat može da izbere vsjaka ot dvete subektivni proekcii na dejstvieto" [29]. 19 In our opinion, this statement is illuminating in explaining several competing uses of the perfective and imperfective aspects in performative verbs in Bulgarian. However, regarding verbal tense, in another paper the following is stressed: "Izkazvanijata-dejstvija iziskvat glagolite da bădat zadălžitelno v segašno vreme"20, which implies the use of the imperfective aspect [33]. Despite claims that the present imperfective is obligatory in performative utterances in Bulgarian, in various papers we find examples with the future perfective:

Šte te pomoljaPF-FUT da mi dadeš tazi kniga za malko [I will ask you to lend me this book] [29]

Šte kažaPF-FUT, če tova e napravo xuliganstvo [I will say that this is really bad manners] [34]

Šte te pomoljaPF-FUT da mi pomogneš utre pri prenasjaneto

[I will ask you to help me move house] [35]

18 Note that the perfective present form (poprošu) in Russian functions as a simple future and therefore the choice of the perfective automatically shifts a performative utterance into the future.

19 [Pragmatic elements in aspect use appear when the Speaker can choose between the two subjective perspective on the action] This study tackles the phenomenon of aspectual concurrence in utterances with various communicative characteristics including performative utterances.

20 [Pragmatic elements in aspect use appear when the Speaker can choose between the two subjective perspective on the action] This study tackles the phenomenon of aspectual concurrence in utterances with various communicative characteristics including performative utterances. 
Dobăr den, docent Draganov. Znaja, če ste mnogo zaet, no vse

pak šte popitamPF-FUT dali šte možete da mi otdelite njakolko minuti? ([34]: 70) [Good day Professor D. I know you are very busy, but nevertheless I will ask you if you can dedicate a few minutes to me]

Among specific research dedicated to performatives in Bulgarian we should mention the very recent doctoral thesis entitled "Performativi i performativi izkazvanija $\mathrm{v}$ săvremennija bălgarski ezik" by Marija Žereva, defended on 5 April 2012 at the University of Sofia. This study offers a detailed classification and analysis of performative utterances in Bulgarian (assertive, commissive, directive, declarative, expressive) and analyses their function in different communicative situations. It is however true to say that the pragmatic functions of the tense and aspect of performative verbs in explicit performative utterances are not the specific focus of analysis of the thesis, although regarding the tense-aspectual characteristics of performative verbs the author does say: "V bălgarski ezik eksplicitnite performativni izkazvanija se predavat $\mathrm{s}$ formi na segašno vreme, nesvăršen vid, po-rjadko $s$ formi ot svăršen vid pri da-konstrukcija na glagola molja/pomolja" 21 ([36]: 29). Greater attention and space are dedicated to the role of aspect in implicit performative utterances and in particular when they are imperative (pp. $33 \mathrm{ff}$.).

Thus the issue of the use of other tense-aspectual forms remains open. Indeed, a closer examination of the tenseaspectual use of performative verbs in Bulgarian reveals that the situation is more complex than it may seem and that both tense (which may often be future) and aspect (which, in the future, may also be perfective as well as imperfective) must be considered.

As stated above, in performative acts in Bulgarian the present imperfective form is widely used, while unlike in other Slavic languages, the perfective in the present is not used in performative utterances as an indicator of illocutionary force. 22 The cases in which we may use the perfective performative verb are limited to the periphrastic future tense. Table 2 shows examples of the use of the imperfective (in the present) and of the perfective (in the periphrastic future) in Bulgarian:

21 [Pragmatic elements in aspect use appear when the Speaker can choose between the two subjective perspective on the action] This study tackles the phenomenon of aspectual concurrence in utterances with various communicative characteristics including performative utterances.

22 Cf. in this connection Russian skažu, poprošu, Czech řeknu, poprosím (although rare), Slovak poviem, poprosim, Polish powiadam, poproszę and the impossible *kaža, *pomolja in Bulgarian. Indeed the perfective present in Bulgarian is not normally used in independent clauses (see also Dickey 2000:76). We can only indicate some cases (mainly with verba dicendi) such as Da ti kaža, če si goljam glupak, Da te/Vi pomolja za edna usluga usluga which can be considered a reduced form of utterances such as Iskam / Bix iskal / Moga da ti kaža, če si goljam glupak oppure Iskam / Bix iskal / Moga li da te/Vi pomolja za edna usluga. This type of expressions is beyond the scope of our research.
TABLE II.

\begin{tabular}{|c|c|}
\hline $\begin{array}{l}\text { Imperfective } \\
\text { (Present Tense) }\end{array}$ & $\begin{array}{c}\text { Perfective } \\
\text { (Periphrastic } \\
\text { TENSE) } \\
\end{array}$ \\
\hline $\begin{array}{l}\text { Naznačavam IPF-PRES } \\
\text { mestnik! [I appoint you moj za- } \\
\text { substitute!] }\end{array}$ & \\
\hline $\begin{array}{l}\text { Poddăržam } \\
\text { Ženie! [I support your offer!] }\end{array}$ & ----- \\
\hline $\begin{array}{l}\text { Nastojavam IIF-PRES da se maxne } \\
\text { uveličenieto na akciza vărxu } \\
\text { rakijata! [I insist on cancelling the } \\
\text { rise in excise duty on the grape } \\
\text { brandy] }\end{array}$ & $\begin{array}{l}\text { I ednokratno šte nastoja }{ }^{\text {PF-FUT }} \text { da se } \\
\text { polzva ljubezen ton, Alva. [And I } \\
\text { will insist once and for all that you } \\
\text { use a polite tone, Alva] }\end{array}$ \\
\hline $\begin{array}{l}\text { Molja }{ }^{\text {IPF-PRES }} \text { te da mi se obadiš. [I } \\
\text { ask you to call me] }\end{array}$ & $\begin{array}{l}\text { Samo šte te pomolja }{ }^{\text {PF-FUT }} \text { da bădeš } \\
\text { tărpeliv i da me izslušaš. [I will } \\
\text { only ask you to be patient and to } \\
\text { listen to me] }\end{array}$ \\
\hline $\begin{array}{l}\text { Kazvam IPF-PRES }{ }_{\text {ti, če e opasno... [I }} \\
\text { tell you - it's dangerous...] }\end{array}$ & $\begin{array}{l}\text { Šte ti kaža }{ }^{\text {PF-FUT }} \text {, če tova si e samata } \\
\text { istina. [I will tell you that this is the } \\
\text { truth itself] }\end{array}$ \\
\hline $\begin{array}{l}\text { Săvetvam IPF-PRES te da pročeteš } \\
\text { knigite na B. [I advise you to read } \\
\text { the books of V.] }\end{array}$ & $\begin{array}{l}\text { Az šte te посьветвам }{ }^{\text {PF-FUT }} \text { da } \\
\text { vnimavaš malko poveče v časovete. } \\
\text { [I will advise you to pay more } \\
\text { attention in class] }\end{array}$ \\
\hline $\begin{array}{l}\text { Želaja }{ }^{\text {IPF-PRES }} \text { ti da bădeš običana i } \\
\text { zaobikolena ot mnogo i istinski } \\
\text { prijateli! [I wish you to be loved } \\
\text { and surrounded by many, true } \\
\text { friends!] }\end{array}$ & $\begin{array}{l}\text { Čestit rožden den, Lovče! Šte ti } \\
\text { poželaja-FuT da si živa i zdrava... } \\
{[\text { Happy birthday, Lovche. I will }} \\
\text { wish you to be alive and well ...] }\end{array}$ \\
\hline $\begin{array}{l}\text { Kălna IPF-PRES se, če kazvam } \\
\text { istinata! [I swear that I am telling } \\
\text { the truth!] }\end{array}$ & $\begin{array}{l}\text {...šte se zakălna PF-FUT, če tazi } \\
\text { pensija zaslužavat săšto taka J. X., } \\
\text { E.D. [I will swear that the same } \\
\text { pension is also deserved by J.X., } \\
\text { E.D] }\end{array}$ \\
\hline
\end{tabular}

Up to now we have observed a rather regular distribution of the aspects in Bulgarian: in the present we always find the imperfective verb while in the future the verb can also be perfective. The situation may therefore seem similar to that of Russian: in fact in Russian, analysis of the tense-aspectual characteristics of performative utterances concentrates mainly on the role played by the aspectual opposition of performative verbs: imperfective in the present, and perfective in the future. 23

If instead we use the tense of the verb as our reference point, the situation in Bulgarian differs from the situation in Russian. The two futures, Russian and Bulgarian, in our opinion, should not be treated in the same way. The Russian simple (synthetic) future form is in reality, as we have already stated, the perfective verb conjugated in the present (in other words, the perfective present), while the Bulgarian future has a specific morphological form consisting of the particle šte + verb (imperfective or perfective) conjugated in the present ([4]: 163).24

Moreover, in the performatives in Bulgarian we find a further particular case which distinguishes it from the other

\footnotetext{
23 This approach is normal for "aspecto-centric" languages such as Russian.

24 This approach is normal for "aspecto-centric" languages such as Russian.
} 
Slavic languages, i.e. the possibility of using in the future, alongside the perfective, the same imperfective verb that we use in the present:

Săšto šte te moljaIPF-FUT da mi pratiš i săstavkite na Psanola. [I will ask you to send me the components of Psanol]

...az šte te săvetvam IPF-FUT da si izkaraš bakalavărskata stepen v Sofija i sled tova da zamineš samo za magistăra văv Francija. [I will advise you to get a bachelor degree in Sofia and then go to France and do a master]

\section{TENSES AND ASPECTS IN PERFORMATIVES IN BULGARIAN AND POSSIBLE LINKS WITH LINGUISTIC POLITENESS}

Below we examine several performative verbs 25 in Bulgarian used in performative utterances which have been classified on the basis of the possible tense-aspectual forms.

The following three types of use of tenses and aspects in the performatives in Bulgarian can be identified:

performatives for which only one tense-aspectual form is possible (which will obligatorily be the imperfective present);

performatives for which two forms can be combined, i.e. imperfective present + periphrastic perfective future (it is impossible to combine imperfective present + analytical imperfective future);

performatives for which three forms are possible: imperfective present + analytical perfective future + analytical imperfective future. The latter can only be added only when combination b) is already present. "Table III" shows the above more clearly.

TABLE III.

\begin{tabular}{|l|l|l|}
\hline \multicolumn{1}{|c|}{ Imperfective Present } & \multicolumn{1}{|c|}{ Perfective Future } & Imperfective Future \\
\hline Zabranjavam (ti, vi) & X & X \\
\hline Kanja/pokanvam (te, vi) & X & X \\
\hline Predlagam (ti, vi) & ste (ti, vi) predloža & X \\
\hline Želaja (ti, vi) & Ste (ti, vi) poželaja & X \\
\hline Molja (te, vi) & Šte (te, vi) pomolja & Śte (te, vi) molja \\
\hline Săvetvam (te, vi) & Ste (te, vi) posăvetvam & Ste (te, vi) săvetvam \\
\hline
\end{tabular}

At this point several questions are posed. The first concerns the role played by verbal aspect in the structure of the performative utterance in Bulgarian, considering the fact that in the same speech act, the same imperfective performative verb can be used both in the present and in the future (in addition to the perfective performative verb in the future). If we really are discussing the same illocutionary act, what is the specific function of the combination of tense and aspect? Furthermore, in what way are the tense-aspectual forms linked to the specific type of speech act and why does

\footnotetext{
Russian.
}

this particularity concern only some of the aspectual pairs of performative verbs?

Given that the illocutionary acts analysed below aim to influence the Hearer, it might well be opportune to analyse these utterances in the context of dialogue as social activity, and therefore, as linguistic politeness phenomena. In this case, we must inevitably consider the interpersonal distance/relations between the Speaker and the Hearer.26 Our analysis will be based in particular on the work of G. Leech [15], Brown \& Levinson [16] and Brown \& Gilman (1960).

For example Leech's tact maxim: “(a) Minimize costs to other [(b) Maximize benefits to other]" (1983: 132) according to which the degree of politeness is handled in terms of costs and benefits for Hearer and Speaker, as expressed on a "cost-benefit scale" (Leech 1983: 107) can be applied to a number of illocutionary acts which involve the Hearer more deeply. It is also important in our research for the Hearer to be able to choose his behaviour (whether to act or not) as represented on an "optionality scale" (Leech 1983: 108). Leech's considerations on conversation theory intertwine with Brown and Levinson's politeness analysis and, in particular, with the concept of negative and positive politeness. Negative politeness consists in the ability to use and manage the illocutionary force of the act with the aim of maintaining distance between the Speaker and the Hearer of the speech act, thus offering the interlocutor a way out, a way of saving negative face, 27 allowing him to feel that a reply (or reaction) is not compulsory (Brown \& Levinson 1987: 70). In contrast, positive politeness is oriented towards the Hearer's positive face, 28 and is based on reducing distance. The Hearer is treated as "one of the group", as svoj while the act's potential threat is minimised thanks to the presupposition that in general the Speaker wants what the Hearer wants (ibid.)

Regarding the interpersonal relations that over the centuries have characterised the evolution of Bulgarian society, it has been shown that positive politeness was dominant up to the mid-nineteenth century (and in rural areas is still dominant today), while negative politeness penetrated Bulgarian society from the West, first of all in the cities (Mladenova 2007). The acquisition of Western models of politeness began at the end of the nineteenth century, after liberation from Ottoman domination in 1878 and with the construction of modern Bulgarian society. However this

26 Cf. in this connection the application of linguistic politeness theories, and especially that of Brown \& Levinson, to the use of verba aspect in the imperative in Slavic languages (Benacchio 2010). This approach has allowed a new explanation to be put forward regarding strategies for the choice of verbal aspect in imperative utterances.

27 Cf. in this connection the application of linguistic politeness theories, and especially that of Brown \& Levinson, to the use of verbal aspect in the imperative in Slavic languages (Benacchio 2010). This approach has allowed a new explanation to be put forward regarding strategies for the choice of verbal aspect in imperative utterances.

28 Positive face instead is defined as "the positive consistent selfimage of 'personality'(crucially including the desire that this self-image be appreciated and approved of) claimed by interactants" (Brown \& Levinson 1987: 61). 
process is still not considered complete, especially in terms of social distance and interpersonal solidarity, since the system remains hybrid and solidarity is often only formal (i.e. artificial and insincere) (Paskalev 2011: 76).

Let us now attempt to answer the questions posed earlier, analysing the contexts of use and the semantic-pragmatic meaning of the three types of tense and aspect use of listed above.

\section{A. Performative Verbs Which Only Allow One Form: the Imperfective Present}

Imperfective performative verbs in the present are used in illocutionary acts when what is expressed by the act is considered by the Speaker to be beyond discussion, in the sense that no continuation of dialogue is planned. In these cases Benveniste speaks of self-referentiality (since the act is at the same time a speech act and a real action (cf. Benveniste 1966: 273-274).

In some cases the utterance act centres on the personality and volition of the Speaker since there is a presumption that it is possible to ask with authority because the administrative and social status of the Speaker allows it (examples 8, 9, 12), because the Speaker is specifically vested with the authority to exercise certain functions (10), or because one wishes to disclose one's position vis-à-vis something concerning the Hearer (11):

- (8)V čest na Nejno Veličestvo krăštavamIPF-PRES tozi grad Izabela i go posveštavam na pametta na zaginalite tuk. [In the name of Her Majesty I name this city Isabella and dedicate it to all those who fell here]

- (9)NaznačavamIPF-PRES te za moj zamestnik! [I appoint you as my substitute!]

- (10)T., pomilvamIPF-PRES te i ti ostavjam života. Tja go iska. [I pardon you and let you live. It is she who wishes it]

- (11)ZabranjavamIPF-PRES Vi da pišete za detskata gradina bez da me pitate! [I forbid you to write about the nursery school before having asked me!]

- (12)Ot dnes ti zabranjavamIPF-PRES da govoriš za lov. [From today I forbid you to talk about hunting]

In the case of examples (8)-(10) Leech's claim that "such illocutions tend to be neutral as regards politeness (Leech 1983: 105) is valid. Consequently, neither the aspect nor the tense of the performative verb can play any particular role here since the use of the specific performative verbs (in specific illocutionary acts) is determined by a special rituality which calls for the use of particular formulas or formulations (krăštavam, naznačavam, pomilvam). In other cases too the total absence of "room for manoeuvre" concerning tense and aspect can be determined by the social roles and functions of the Speaker (zabranjavam in examples 11-12). The universal, classic form of expression of performatives is thus maintained, i.e. the first person of the imperfective present in the indicative mood, which can therefore be considered "neutral" from the point of view of politeness.

In other cases (13-15) we are dealing instead with acts of proposal or invitation addressed to the Hearer who is in turn free to accept or not accept. In any case the dialogue is expected to continue (accepting, refusing, thanking, excusing and so on). Thus for example the sentence "Kanja te na roždenija si den" [I invite you to my birthday party] means that (i) the Speaker wishes to see the Hearer at the Speaker's birthday party; (ii) the Speaker believes that this will be also welcome to the Hearer; (iii) the Speaker transmits this wish to the Hearer; (iv) the Hearer acknowledges the wish expressed by the Speaker; (v) the Hearer can decide whether or not to accept. Here are some examples of invitation (13-15) and proposal (16):

- (13)Kanja IPF-PRES te na edno neverojatno parti s neverojatni emocii. [I invite you to an incredible party with incredible emotions]

- (14)KanjaIPF-PRES Vi da se razxodite s meni $\mathrm{z}$ plovdivskite ulici... [I invite you to take a walk with me around the streets of Plovdiv...]

- (15)PokanvamIPF-PRES te sa dojdeš da ni vidiš. [I invite you to come and see us]

- (16)PredlagamIPF-PRES ti da pročeteš ošte vednăž kakvoto săm napisala. [I propose that you read once again what I wrote]

Utterances (8)-(16) can be analysed on the basis of Leech's maxims, in particular the tact maxim. Thus in examples (8)-

from the point of view of Leech's illocutionary functions we are dealing with the collaborative function, in which the illocutionary goal "is indifferent to the social goal" (Leech, 104). In contrast, examples (13)-(16) express the convivial function of the illocutionary acts identified by Leech, on the basis of which every opportunity is used to express respect for, and closeness to the Hearer (Leech 1983: 105) - it is presumed that the invitation (and the proposed action) are welcome to the addressee and that therefore there is objectively no need to "soften" the request. In this case too, the performative verb is in the imperfective aspect. Moreover, the Hearer's freedom to decide in (13)-(16), is in our opinion, the most important, defining factor in this type of speech act and expresses the Speaker's great "social intelligence" in allowing this eventuality.

\section{B. Performative Verbs Which Allow Two Forms: Imperfect Present + analytical Perfective Future}

The second type can use either the imperfective in the present (examples 17, 19,21) or the perfective in the future (examples 18, 20, 22): 
- (17)ŽelajaIPF-PRES ti da bădeš običana i zaobikolena ot mnogo istinski prijateli!29 [I wish you to be loved and surrounded by many true friends!]

- (18)Čestit rožden den, Lovče! Šte ti poželajaPF-FUT da si živa i zdrava... [Happy birthday, Lovche. I will wish you to be alive and well ...]

- (19)Zatova pak podčertavamIPF-PRES, če broja na procedurite $\mathrm{i}$ intervala meždu tjax se opredeljat strogo individuano pri vseki pacient. [For this reason, I stress that the quantity of procedures and the intervals between them are determined for each patient in a strictly individual manner]

- (20)Šte podčertajaPF-FUT, če partn'orstvoto ni s bălgarskata obštnost e prioritet za dejnostta na posolstvoto. [I will stress that our partnership with the Bulgarian community is a priority in the embassy's activity]

- (21)... napomnjamIPF-PRES vi, če citiranite $\mathrm{v}$ statijata danni sa za fevruari mesec 2012. [...I remind you that the data cited in the article refer to the month of February 2012]

- (22)Šte ti napomnjaPF-FUT, če publičnoto obsăždane na moderatorskite dejstvija se nakazva. [I will remind you that public discussion of the moderator's actions is punishable]

In contrast with examples $(17,19,21)$, sentences $(18,20$, hint at a greater interpersonal distance which would appear to be conveyed by the future of the performative verb distancing the illocutionary act from the actual moment of speaking. This combination 'imperfective present + periphrastic perfective future' is quite regular in verbs such as zajavjavam (šte zajavja), podčertavam (šte podčertaja), napomnjam (šte napomnja), kaža (šte kaža), priznavam (šte priznaja), želaja ti/Vi (šte ti/Vi poželaja), whose purpose is not to "get something done" but to assert or communicate something. Moreover, the perfective form focuses attention on the fact that the wish is linked to a specific unique occasion (poželaja, kaža, napomnja, zajavja) 30 thus reinforcing the resultative component of the illocutionary act.

This type of illocutionary acts should be rather impermeable to the functions of linguistic politeness since they present a "sterile" opinion of the Speaker. In our opinion however, choosing the future (perfective) of the performative verb enables the Speaker to maintain (or increase) distance from the Hearer, thus objectifying the content of the utterance and avoiding the assumption of personal responsibilities. This protects not only the Hearer's space but also that of the Speaker, and the latter's wish to

29 Positive face instead is defined as "the positive consistent selfimage of 'personality'(crucially including the desire that this self-image be appreciated and approved of) claimed by interactants" (Brown \& Levinson 1987: 61).

30 Positive face instead is defined as "the positive consistent selfimage of 'personality'(crucially including the desire that this self-image be appreciated and approved of) claimed by interactants" (Brown \& Levinson 1987: 61). present the facts as objective and real (cf. examples 20 and 22). This is particularly evident in the case of example $(16 / 18)$ where, given the inherently "positive" semantics of the verb (poželaja PF [wish]), it is also possible to speak of the Speaker's desire to make the content of the wish expressed formal, thus obtaining a greater formalisation of the interpersonal relation and in this way showing greater politeness and respect. In this way the Hearer is promoted to a higher status than the position occupied normally in interpersonal relations with the Speaker.

\section{Verbs which allow three forms: imperfect present + analytical perfective future + analytical imperfective future}

As previously mentioned, the most interesting case, which distinguishes Bulgarian from the other Slavic languages (as regards the use of tenses and aspects), consists of the possibility of using a performative verb (i.e. the aspectual pair of the same verb) in three different forms (imperfective present, analytical perfective future, analytical imperfective future), which allows the maximum realisation of gradations in interpersonal relations, especially as regards distance between Speakers. This use in particular concerns a number of performative verbs which will be analysed in the following section.

In the following examples the request 31 is expressed by an imperfective present performative verb and leaves the addressee the freedom to perform or not perform the action requested. In this sense, above all in directive acts (with which one usually asks someone to "act" and which represent Leech's competitive illocutionary function), the imperfective present is perceived as polite and neutral:

- (23)MoljaIPF-PRES te da dojdeš (implied: if you can and will) [I ask you to come]

- (24)MoljaIPF-PRES te da mi doneseš knigite. [I ask you to bring me the books]

- (25)Molja IPF-PRES Vi da mi donesete knigite. [I ask you to bring me the books]

- (26)MoljaIPF-PRES Vi da govorite po-visoko. [I ask you to speak louder]

- (27)Molja IPF-PRES Vi da govorite po-bavno [I ask you to speak more slowly]

Analysing examples (23-27): molja te/Vi [I ask/beg you]) we see that the Speaker: (i) believes that the interlocutor is capable of granting his requests, (ii) believes that locutor/interlocutor relations are such that he may express the request for the action; (iii) requests that the Hearer act out of politeness (not as an obligation, and thus "if he can"); (iv) as regards the addressee's "response", i.e. his willingness and decision to act, the Speaker expects the Hearer to grant his request because he is certain that the reciprocal relations

\footnotetext{
31 On the use of the verbs molja-pomolja and prosit'-poprosit' see
} also Slavkova 2014 
(whether informal "T-T" or formal "V-V") 32 will ensure positive politeness "in the opposite direction" (i.e. that the interlocutor wants the same thing as the Speaker).

In the case of a symmetrical but formal "V-V" relations, and therefore one of greater social distance between the Speakers, respect of the principles of negative politeness becomes important, and therefore for this type of illocutionary act, requests in the conditional in the form of a question are preferred: Bixte li mi pomognali? [Could you help me, please?]; Bixte li mi donesli knigite, ako običate? [Could you bring me the books, please?] or other implicit requests: Dali šte možete da mi pomognete? [Could you help me?]; Dali šte možete da mi donesete knigite? [Could you bring me the books, please?]

However, in all the cases of symmetrical relations, the form of the performative verb is the same (imperfective present). Distance is adjusted by symmetrical use of the pronouns of address ti (T-T) and Vie (V-V).33

Let us now analyse the examples with a perfective future performative verb. In this case linguistic politeness, i.e. the distance between Speakers takes on importance, as a result above all of the particular combination of perfective and future. Concerning the perfective for example, a recent paper by $\mathrm{R}$. Benacchio (2010) on the role of verbal aspect in the imperative in linguistic politeness phenomena makes it clear that in Slavic languages the perfective in the imperative has the ability to act as a face-saving factor for the very reason that the perfective, being a form that is suited to maintaining distance, corresponds to greater formality and negative politeness in the Slavic imperative.

Regarding performatives in Bulgarian it should be noted that the periphrastic future form itself (using the invariant particle šte) affects interpersonal distance, further increasing it. Therefore, the utterances we shall examine here can be dealt with from the point of view of the degree of politeness on the basis of the different communicative situations and, in particular, on the basis of their competitive illocutionary function.

In the utterances with the addressee as symmetrical "Vie" (i.e. V-V) the future tense of the perfective verb allows various scenarios to be developed. In (28), for example, the

\footnotetext{
32 Regarding interpersonal relations our approach is based on the work of Brown \& Gilman 1960 which formulates the conditions governing the use of second person singular $(\mathrm{T})$ and plural $(\mathrm{V})$ of the pronouns of address in European languages. These conditions are based especially on nonreciprocal power semantics (p.255) and on solidarity semantics (pp. 257 ff.). In our study we take into consideration only symmetrical "horizontal" relations, or relations of social equality, which manifest themselves through greater or lesser distance. The V-V relation has a connotation of formality and respect, while the T-T relation conveys familiarity and intimacy.

33 Here we do not consider asymmetrical relations between the interlocutors ( $\mathrm{T}-\mathrm{V})$, where the same requests, especially if followed by "da+perfective verb" as in examples 23-24, may be interpreted as overcoming interpersonal distance. In such cases the implicit request form would be preferable: Moga li da Vi pomolja da govorite po-visoko? May I ask you to speak a bit louder?Moga li da Vi pomolja da govorite po-bavno? (May I ask you to speak a bit slower?) (with possible explanation of the reasons: če lošo Vi čuvam (because I can't hear you); če ne svičko razbiram (because I can't understand).
}

Speaker acknowledges and maintains his distance from the addressee of the request, accepting the fact that it is up to the Hearer to make the final decision:

- (28) Šte Vi pomolja ${ }_{P}^{F-}{ }_{F U T}$ da mi dadete săvet ili informacija za liuteratura po văprosa. [I will ask you to give me some advice or information about the literature on that subject]

In this type of use, the horizontal distance and the formality of symmetrical relations between the speakers are maintained, leaving the addressee freedom to choose however. In this case it is indeed a case of "asking courteously".34

Yet there are cases (examples 29-30) when the Speaker may consider his own social status (determined perhaps by a specific role) as being higher than that of the addressee of the request:

- (29)Trosnatija glas na edna ot služitelkite izcepva: "Šte Vi pomoljaPF-FUT da napusnete ofisa. Tova ne e čakalnja!"; [The tart voice of one of the attendants was heard: "I will ask you to leave. This is not a waiting room!"]

- (30)Šte Vi pomoljaPF-FUT da mi pokažete kasovata beležka (i ako ima razlika ili netočnost...) [I will ask you to show me the receipt (and if there's a difference or a mistake ...)]

In examples (29) and (30), thanks specifically to the perfective in the future, the request, while remaining formally polite, is perceived as an imposition since the actions which form the object of the request are not welcome to the Hearer.35 In this case we may talk of an authoritative request that is close to being an order. No space is left for discussion and personal assessment by the Hearer and the illocutionary act thus constructed becomes an expression of the vertical distance between the speakers. However, since the request is formally polite, the Speaker is "forced" to minimise the negative effect on the Hearer and to motivate the act ("This is not a waiting room!" [This isn't a waiting room]; "i ako ima razlika ili netočnost"[and if there's a difference or a mistake]).

Of particular interest are the situations where relations are closer and more informal, and distances are reduced (examples 31-34). In these cases, use of the formal and polite perfective, (šte te pomoljaPF-FUT) exhibits a voluntary creation of distance by the Speaker (in contrast with the "TT" solidarity relation) which enables him to express both the request (possibly unwelcome to the Hearer) and a critical assessment of the Hearer's previous actions:

34 Cf. Colella (2009) on the fact that the same verb pregare in Old Italian can be used both to "ask with courtesy" (chiedere per cortesia) and to "ask with authority" (chiedere per autorità). As we shall see below, in Bulgarian the verbs of the aspectual pair "molja - pomolja" in their tensed forms can express the same shade of meaning.

35 The utterance thus constructed implies asymmetrical social relations (superior to inferior) and in any case, the absence of equality (see also Brown \& Gilman 1960). 
- (31)A sega naj-učtivo šte te pomoljaPF-FUT da se dăržiš prilično i da ne komentiraš točno po tozi način gramotnostta na potrebitelite. [And now I will kindly ask you to behave yourself and not to comment on the literacy of the consumers]

- (32)Săvsem učtivo šte te pomoljaPF-FUTbez da znaeš, da ne si pozvoljavaš da komentiraš nešta, koito ne sa taka (...). [I will ask you most kindly not to comment on things about which you don't know anything and which are not what you think they are]

In these cases, given the unwelcome (and perhaps unexpected) content of the request, and to "attenuate" the authoritativeness of the perfective associated with the presumed "costs" for the Hearer in performing the request, the speaker uses attenuating adverbs such as samo [only] (example 28/33), edinstveno [only] (example 29/34), učtivo [kindly], (examples 26/31-27/32), malko poveče [a little more] (example 30/35) etc.:

- (33)Edinstveno šte te pomoljaPF-FUT da dobaviš tuk i tova koeto si složil v drugata tema. [I will only ask you to add here what you have put in the other topic]

- (34)Samo šte te pomoljaPF-FUT da bădeš tărpeliv i da me izslušaš. [I will only ask you to be patient and to listen to me]

- (35)Az šte te posăvetvamPF-FUT da vnimavaš malko poveče $\mathrm{v}$ časovete. [I will advise you to pay a little more attention in class]

The future used in contexts (31-35) cannot be defined a true future but is a conventional form, almost a fixed formula performing a particular pragmatic function. Clearly the act of the request takes place at the moment of speaking, i.e. in the present, but the distancing of the act of requesting from the actual moment of speaking thanks to the future tense, combined with the perfective aspect, produces the effect of greater interpersonal distance which clashes with the informal " $\mathrm{T}-\mathrm{T}$ " relation and transforms the request into a kind of order. This order (authoritative request) as we have seen, in turn can be "attenuated" using certain adverbial elements.

Instead, in the case of "V-V" relations (28)-(32), it can perform the dual function of "asking politely" if it is a question of horizontal distance (28) and of "asking authoritatively" in the case of asymmetrical relations (even if only presumed) - (29) and (30).

The use in performative utterances of imperfective verbs in the future (alongside imperfectives in the present and perfectives in the future) appears somewhat strange and is difficult to explain:

- (36)(Az Vi obeštavam zanapred da Vi piša kolkoto iskate takiva dopiski protiv opozicijata), само šte $V i$

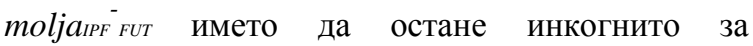
публиката. [(I promise you that from now on I will be writing for you as many reports against the opposition as you want) but I will ask you to leave my name incognito for the readers]
- (37)Citiranijat drudo dogovor sledva da băde prekraten na osnovanie čl. 326 sčitano ot ... г., kato za sroka na predizvestie šte Vi moljaIPF-FUT da mi băde izplateno dălžimoto văznagraždenie. [The aforementioned labour contract has to be suspended on the grounds of art. 326, reckoned from ..., and I will ask you to pay me what's due for the period of notification]

In examples (36) - (39) we see that it is the objectively existing social distance between the interlocutors $(\mathrm{V}-\mathrm{V})$ that determines the use of the future. Use of the imperfective is instead most likely linked to a personal, internal distancing of the Speaker from the addressee. (36). All the more so because in general the Hearer may represent an institution or organisation, and therefore the Speaker is addressing a legal person, or a generalised Hearer (39-41). It is no coincidence that this formulation is particularly characteristic of various types of legal relations. In this sense, such speech acts are close to being "representatives":

- (38)... poradi koeto šte Vi moljaIPF-FUT da se dade văzmožnost na $\mathrm{p}$ o-kăsen etap da ja predjavat po graždanski red. [...And because of that I will ask you to be given me the opportunity to lay claims according to the civil order]

- (39)... kăm dnešna data njama zapazeni takiva prepiski v arxiva), poradi koeto šte Vi moljaIPF-FUT da băde priobšteno tova pismo kăm deloto. [(Up to the present day there are no reports like these in the archives) and because of that I will ask you to add this letter to the case]

If such utterances are compared with Russian (40) they very closely resemble the manner in which institutions are addressed using a legalistic or "public administration" style:

- (40) (V slučae nesoglasijasuda s kakimi-libo svedenijami, soderžaščimisja $\mathrm{v}$ predstavlennyx dokazatel'stvax i ob'jasnenijax) prošuIPF-PRES sud istrebovat' eti svedenija iz sootvetstvujuščix organov i oprosit' svidetelej. [If the court disagrees with any of the data in the presented proofs and evidence, I ask the court to request the required information from the appropriate authorities and interview the witnesses]

From the examples analysed (37-39) it is evident that in formal utterances with an imperfective performative verb in the future (V-V: šte Vi molja) the act is totally focused on the actual request. It is not so much the reaction of the addressee that is important to the Speaker (or at least in the illocutionary act in question this reaction takes second place), as the formulation per se, the expressing of the content of the request. In this way it is as if the person of the Hearer were being distanced from the Speaker (or is objectively speaking socially distanced).

Regarding informal solidarity relations (T-T: šte te molja) the situation is more complicated:

- (41)Sega šte te moljaIPF-FUT da ne mi otkazvaš tova, koeto šte te pomoljaPF-FUT. Iskam da te oženja za naj-malkata si dăšterja ... [I will ask you not to refuse 
me and do what I will ask you. I want you to marry my youngest daughter ...]

- (42)Az prigotvix pismoto i utre ministăra šte go podpiše, no šte te moljaIPF-FUT da mi uslužiš s edin zaem ot petnadeset xiljadi leva. [I’ve prepared the letter and tomorrow the minister will sign it but I will ask you to lend me $15000 \mathrm{lv}$.]

- (43)...az šte te săvetvamIPF-FUT da si izkaraš bakalavărskata stepen v Sofijai sled tovada zamineš samo za magistăra văv Francija. [I will advise you to get a bachelor degree in Sofia and then go to France and do a master]

In examples (41-43) the interpersonal distance is minimal and the relation is informal ' $\mathrm{T}-\mathrm{T}$ '. At the same time, the request is expressed in the future - a tense which more than others is suited to expressing distance and formality, as we have seen, including interpersonal distance and formality. There is no doubt that the requests and advice expressed in this way are formal but this formality - especially in the requests - appears to be incongruous, while the advice seems detached and not really interested. Therefore it would appear that Searle's sincerity condition has not been respected. With this strategy, it is as if the Speaker were voluntarily increasing the distance, which in a solidarity relation is minimal by definition. Precisely because of their official, distanced character, requests and advice expressed using the imperfective in the future "clash" with the "T-T" solidarity relation and cannot with any certainty be considered polite, indeed, they are perceived as impositions or as formal advice which in reality do not involve the Speaker.

\section{CONCLUSION}

The analysis carried out up to this point has shown how also in Bulgarian performative utterances obey the rule according to which performative verbs can only use the first person singular of the present indicative. The aspectual form in this case is imperfective and this distinguishes Bulgarian from most of the Slavic languages, which can also use the present perfective.

However, examination of the corpus analysed reveals a much more complex situation: in Bulgarian for example, in addition to the present, a performative utterance can also be expressed in the future, using the periphrastic future. In this case, both the perfective and the imperfective aspects are possible, although the latter is used more rarely. In other words, a greater variety of combinations of tense and aspect in performatives can be observed in Bulgarian.

This led us to opt for a pragmatic type of analysis: we put forward the hypothesis, which at least in some cases has proved to be valid, that tense and aspect in performative utterances can perform particular functions that are especially linked to interpersonal distance and linguistic politeness.

First of all we must bear in mind that since performative utterances coincide with the actual action, they inherently "change the state of things", i.e. they impact on reality, affecting both the Speaker (who in speaking performs the act) and the Hearer. In such utterances the interpersonal dimension therefore acquires particular significance, especially in relation to linguistic politeness phenomena. More precisely, the choice of a performative verb's tense and aspect can contribute to maintaining the distance between interlocutors, to increasing it, but also to reducing it by a variable amount, and at times even to invading the Hearer's personal space and producing an impolite effect.

For example we have seen that for representative acts, use of the future of the imperfective performative offers the Speaker the possibility of reducing the degree of "subjectivity" of the illocutionary act, thus protecting him from assuming responsibility for the content of the propositional part of the utterance. This protects not only the Hearer's personal space but also that of the Speaker. In other words, the role of the future tense combined with the perfective aspect is fundamental in Bulgarian for controlling interpersonal distance and for negative politeness.

The illocutionary potential of directive acts (requests and advice for example) is of particular interest. In general, the imperfective performative present is the most appropriate for these acts, and is also the most used in informal solidarity relations (especially if the request is welcome to the addressee), since it is in harmony with interpersonal closeness and transmits the highest degree of positive politeness.

In contrast, the same directive acts, which by their nature are highly "invasive" (face-threatening since their aim is to influence the addressee) clash with formality of relations (also in symmetrical relations) and consequently are less used in formal/official contexts, especially if the request is not welcome to the Hearer. To ensure communicative success in these cases, a more formal and polite form is usually chosen (for example the conditional, descriptive forms, interrogative forms etc.) The more unwelcome the content of the request, the politer the form of verb needs to be.

If instead, to express the same acts we use the perfective in the future, which is a more formal way of asking for a favour, greater distance can be presumed between the Speaker and the Hearer: in the case of informal relations, which are characterised per se by less distance, a directive utterance expressed using this form may be perceived negatively, almost as an imposition; yet in formal relations the same form may be interpreted as a polite request (especially if it is welcome). This is why the performative verb in the future is more appropriate for expressing negative politeness in formal relations, while in informal relations, which by definition involve solidarity, it may transmit greater authoritativeness or an attitude of cold detachment.

In the case of the use of the imperfect aspect in the future, the central element in the utterance is the Speaker's actual request (or advice), and the desire to convey these to the Hearer: the Speaker has no expectation of any immediate reaction from the Hearer. This use of the imperfective future can be linked to the indefinite semantics of the imperfective, which generally only allows an action to be named, without 
focusing attention on the consequences of the illocutionary act. Such use - which we stress does not consider the Hearer's reaction - is opportune (and more frequent) especially in contexts characterised by formality and distance.

On the other hand, in informal interpersonal relations, use of the imperfective aspect in the future gives rise to a clash, due to the "artificial" distance which the Speaker desires and creates, and which the Hearer finds somewhat surprising and puzzling. This produces an impoliteness effect in the request with the imperfective in the future. Even advice, which can be thought of as being welcome to the Hearer, may sound formal, cold and unconvincing if expressed in this way. In other words, it may express "indifference".

Thus the use of a directive performative in the future imperfective in situations characterised by formal relations sounds polite and distanced, while in informal relations it is out of place and gives rise to an "impolite effect".

To sum up, we claim that the communicative meaning of a performative utterance in Bulgarian is the result of synergy between the linguistic and extra-linguistic factors in the illocutionary act. In fact not only the lexical semantics of the components of the utterance, but also the strictly grammatical instruments of the utterance and the handling of the degree of interpersonal distance between the interlocutors (whether relations are based on solidarity or power, informality or formality etc.) allow the Speaker to modulate his communicative intention. In Bulgarian in particular, the perfective and imperfective forms in the future of performative verbs perform a fundamentally pragmatic function linked to linguistic politeness, while the forms in the present (which are only imperfective) are more neutral and less significant from the point of view of pragmatics.

\section{REFERENCES}

[1] E.V. Paducheva, Taxonomic categories and semantics of aspectual opposition. // Temporal reference, Aspect and Actionality, Vol.1. / edited by P.M.Bertinetto, V. Bianchi, J. Higginbotham \& M. Squartini - Torino: Rosenberg \& Sellier, 1995, pp. 71-90.

[2] I. Xaralampiev, Istoričeska gramatika na bălgarskija ezik. Sofia: Faber, 2001, pp. 161-162 [A Historical Grammar of Bulgarian Language] (In Bulgarian).

[3] L. Andrejčin, Osnovna bălgarska gramatika. [Basic Bulgarian Grammar]. Sofiia, Khemus Publ., 19496 pp. 145-146. (In Bulgarian)

[4] V. Stankov, Vreme na glagola [Verb tenses] // Gramatika na săvremennija bălgarski knižoven ezik. // [Grammar of contemporary Bulgarian literary language in three volumes] (In Bulgarian). Vol. II/2, Sofia: Abagar, 1998. - pp. 100-177.

[5] Ju.S. Maslov Vid i leksičeskoe značenie glagola v sovremennom russkom Literaturnom jazyke. [Aspect and lexical meaning of the verb in the contemporary Russian literary language] // Izvestija Akademii nauk SSSR. Otdelenie literatury i jazyka [News of the Academy of Sciences of the USSR, Department of Literature and Languages], vol. VII, issue 4, pp. 303-316. (In Russian)

[6] Z. Vendler, Verbs and Times. // Linguistics and Philosophy, Ithaca, NY: Cornell University Press, 1967. - pp. 97-121.

[7] B. Comrie, Aspect. Cambridge: Cambridge University Press, 1976.

[8] E.V. Paducheva Semantičeskie issledovanija. [Semantic Studies] Moskva: Jazyki russkoj kul'tury, 1996. (In Russian)
[9] T.V. Bulygina, K postroeniju tipologii predikatov v russkom jazyke [Toward constructing a typology of predicates in Russian] // Semantičeskie tipy predikatov [Semantic Types of Predicates] / edited by O.N. Seliverstova - Moscow: Nauka, 1982. - pp. 7-85. (In Russian)

[10] Anna A. Zaliznjak and A. Šmelev, Vvedenie v russkuju aspektologiju [Introduction to Russian Aspectology]. Moscow, Iazyki russkoi kul'tury Publ., 2000. 222 p. (In Russian)

[11] A. Dostál, Studie o vidovém systému v staroslověnštině [A Study of the Aspectual System of Church Slavonic] Praha: SPN, 1954. (In Czech)

[12] J.L. Austin, How to do Things with Words: The William James Lectures delivered at Harvard University in 1955. Oxford: Clarendon, 1962, pp.61-62.

[13] J. Searle, Speech Acts. An Essay in the Philosophy of Language, Cambridge: Cambridge University Press, 1969, p. 57.

[14] H.P. Grice, Logic and conversation. // Syntacs and semantics. Vol.3: Speech acts. / edited by P. Cole and J.L. Morgan - New York: Academic Press, 1975. - pp.41-58.

[15] G. Leech, The principles of pragmatics. London and New York: Longman, 1983.

[16] P. Brown and S.C. Levinson, Politeness : some universals in language usage. Cambridge [etc.]: Cambridge University Press, 1987.

[17] E. Benveniste, Problèmes de linguistique générale [Problems in General Linguistics]. Paris: Gallimard, 1966, p. 271.

[18] S.M. Dickey, Parameters of Slavic Aspect. Stanford: CSLI Publications, 2000

[19] D. Vojvodic, Ob upotreblenii i značenii soveršennogo vida $v$ performativnyx predloženijax-vyskazyvanijax $\mathrm{v}$ slavjanskix jazykax: opyt tipologičeskoj differenciacii [Meaning and use of the perfective aspect in the performative utterances in Slavic languages: a typological distinction // Slavjanskie jazyki: edinicy, kategorii, cennostnye konstanty. Sbornik naučnyx trudov [Slavic languages: items, categories, value constants. Collection of

$$
\text { scientific papers] / edited by }
$$

N.A.Tupikova - Volgograd: Izd-vo VolGU, 2010. - 175-191.

[20] B. Wiemer, Upotreblenie soveršennogo vida $v$ performativnom nastojaščem [Use of the perfective in the performative present] // Acta Linguistica Petropolitana, 2014, 10 (3), 90-113.

[21] I.Ž. Žagar, Performativity as tense and aspect. International review of pragmatics, 3-2, 2011, pp.168-193. doi: 10.1163/187731011X597505.

[22] Iu.D. Apresian, Izbrannye trudy. Tom 2. Integral'noe opisanie jazyka i sistemnaja leksikografija. Izbrannye Trudy [Selected Works Vol. 2. An Integrated description of language and systematic lexicography]. Moscow, Iazyki russkoi kul'tury Publ., 1995, pp. 206, 208, 216, 238-239.

[23] A.V. Bondarko, Teoriia funkcional'noi grammatiki: Temporal'nost'. Modal'nost'. [The Theory of functional grammar: Temporality and modality], Leningrad: Nauka, 1990.

[24] M.Ya. Glovinskaya, Mnogoznačnost' i sinonimija v vidovremennoj sisteme russkogo glagola [Polysemy and synonymy in aspect-tense system of Russian verb]. Moscow: Azbukovnik. Russkie slovar, 2001, p.277.

[25] E.V. Padučeva, Vid i vremja performativnogo glagola [Aspect and tense of the performative verb] // Logičeskij analiz jazyka. Jazyk rečevyx dejstvij [Logical analysis of the language. Language of speech acts.] / edited by N.D.Arutjunova and N.K. Rjabceva, Moscow: Nauka, 1994. -37-42.

[26] B. Comrie, Tense. Cambridge: Cambridge University Press, 1985 , p. 37.

[27] J.K. Krékits, K probleme performativov predpisanija v Biblii [On the problem of prescriptive performatives of command in the Bible] // [The Typology of Aspect: Problems, Research, Solutions] / edited by M. Ju. Čertkova, Moscow: Jazyki russkoy kul'tury, 1998 - pp. 241-248. 
[28] E. Koschmieder, Očerk nauki o vidax pol'skogo glagola. Opyt sinteza.[A study on Polish verb types. A possible synthesis] / Voprosy glagol'nogo vida [Issues of verbal aspect], / edited by Ju.S. Maslov, Moscow: Izd. inostrannoj literatury, 1962. - pp. 105-67.

[29] R. Nicolova, Pragmatičen aspekt na izrečenieto v bălgarskija knižoven ezik [Pragmatic aspect of the sentence in literary Bulgarian] Sofia: Narodna prosveta, 1984, p. 84, 128.

[30] S. Dimitrova, Lingvistična pragmatika [Linguistic pragmatics]. Sofia: Veles, 2009.

[31] B. Georgiev, Rečevite aktove kato predmet na leksikografsko opisanie.[Speech acts as an object of study in lexicography] // LiterNet,23.03.2006, 3(76), 2006. - Retrieved at http://liternet.bg/ publish4/b_georgiev/ rechevite.htm

[32] Kurteva, G. Ilokucija i performativnost $\mathrm{v}$ dialoga [Illocution and performativity in the dialogue] // Foreign Languages for Specific Purposes: Conference Proceedings 4-6 June 1998 Vol. 2 / edited by V. Kjuvlieva-Mišajkova and V. Tačeva - Varna: Medicinski universitet, 2008 - pp. 75-8.

[33] K. Ivanova and R. Nicolova, Nie, govoreštite xora [We, the people who speack]. Sofia: Univ. izd. Sv. Kliment Ohridski, 1995, 93.

[34] S. Dimitrova, Ezikova demagogija [Linguistic demagogy]. Sofia: Naukaizkustvo, 1999, p. 117.

[35] X. Panteleeva, Gramatika na vežlivata reč [Grammar of politeness]. Sofia: Nauka i izkustvo, 1994, p. 94.

[36] M.S. Žereva, Performativi e performativi izkazvanija v săvremennija bălgarski ezik [Performatives and performative utteranses in modern Bulgarian] (Abstract of doctoral thesis in philology, Sofia University "St. Kliment Oxridski", 2011. Retrieved at www.uni-sofia.bg/index.php /bul/.../1/.../avtoreferatM. Jereva.pdf

[37] R. Benacchio, Vid i kategorija vežlivosti v slavjanskom imperative: sravnitel'nyj analiz [Aspect and the category of politeness in the Slavic imperative. A comparative analysis]. München; Berlin: Otto Sagner, 2010.

[38] R. Brown and A. Gilman, The Pronouns of Power and Solidarity. // American Anthropologist 4 (6), 1960 - pp. 24-39.

[39] O. Mladenova, Za vežlivostta $\mathrm{v}$ istoričeska perspektiva [On the politeness from a historical perspective]. // Bălgarska reč, XIII/2007-1, 2007. - pp. 47-67.

[40] N. Paskalev, Komunikativna norma i učtivost [Norms of communication and politeness] // Bălgarski ezik. LVIII-2011, Priloženie, 64-80.

[41] S. Slavkova Performativnoe upotreblenie glagolov prosit'/poprosit' i molja/pomolja $\mathrm{v}$ russkom i bolgarskom jazykax: pragmatičeskaja rol' vida i vremeni [Performative Use of the Verbs prosit'/poprosit' and molja/pomolja in Russian and Bulgarian: The Pragmatics of Aspect and Tense] // SCANDO-SLAVICA, vol. 60, 2014 - pp. 231-252, ISSN: 0080-6765, doi: 10.1080/00806765.2014.984464.

[42] G. Colella, Performativi espliciti in italiano antico [Performatives in old Italian language]. Conference paper of the XXXI Deutscher Romanistentag. - Bonn, Germany, 2009. http://du-se.academia.edu/ GianlucaColella/Papers/338040/Perfomativi_espliciti_in_italiano_a ntico_Performatives_in_old_italian_language_ 